Helena Peričić

Odjel za kroatistiku

Sveučilište u Zadru

hpericic@gmail.com

(D) https://orcid.org/0000-0001-9920-4027

\title{
Hrvatska drama druge polovice $X X$. st.: neki obrasci oblikovanja političke polemike
}

\author{
Croatian playwriting in the second half of the 20th century: \\ some patterns of forming political polemics
}

Sažetak: Druga polovica XX. st. u hrvatskoj dramskoj proizvodnji, poglavito u razdoblju od 1960-ih do početka 1990-ih godina, bogata je djelima koja su (po)služila kao intelektualni i kreativni poligon naspram represivnim okolnostima što su se ticale hrvatskoga političkog i umjetničkog prostora u tadanjoj SFRJ. Sredstva kojima se dramatičari/dramatičarke u motrenom periodu utječu zanimljiva su posebice s književnokomparatističkoga stajališta, s obzirom na to da se dotiču stranih književnosti i povijesti, ali i mita i religijskih sastavnica. Autorica stoga na temelju dramske građe (od M. Matkovića, M. Krleže, A. Šoljana, I. Slamniga, V. Perkovića, Ivana Supeka, T.P. Marovića / pa i nešto ranijih: K. Mesarića i R. Ivšića / do I. Brešana, M. Gavrana, Lade Kaštelan, M. Brumeca i dr.) stvara tipologiju prevladavajućih obrazaca koji - u prostoru koji nije „zapadnoeuropski“ - začudno odjekuju postmoderničkim timbarom. Među tim obrascima prevladavaju: intertekstualnost (u užem smislu riječi), mitološko-religijsko-nadnaravni obrazac, obrazac citatnosti i aluzivnosti, te metonimijski ili povijesni obrazac.

Mnogi su među motrenim tekstovima bili u vrijeme svoga nastanka zanemareni, a neki od njihovih autora marginalizirani sve do 1990-ih, tj. do uspostave nove hrvatske države. Stoga autorica naglašava potrebu za revizijom cjelokupnoga hrvatskog korpusa motrenoga razdoblja, a time i za mogućim redefiniranjem uloge/kvalitete nekih autora koji su ostali u sjeni uže ili šire književne i kazališne recepcije.

Ključne riječi: hrvatska drama, druga polovica XX. st., SFRJ („,bivša Jugoslavija“), ideologija, politička represija i protest, revizija književnosti, intertekstualni obrasci, strana književnost i kultura

Summary: The author discusses the Croatian playwriting of the second half of the 20th century (mostly from the period from the 1960s to the beginning of the 1990s). Playwrights such as M. Matković, M. Krleža, A. Šoljan, I. Slamnig, V. Perković, Ivan Supek, T.P. Marović (as well as some from the first half of the century: K. Mesarić, R. Ivšić), 
together with I. Brešan, M. Gavran, Lada Kaštelan, M. Brumec and others - have been in the centre of attention in the study of this abundant and varied dramatic corpus. Most of the observed dramatists articulated their intellectual and creative potential and demonstrated artistic protest towards various forms of (political) repression and ideological circumstances in the former state of Yugoslavia (SFRJ) through the usage of patterns frequently related to the foreign culture, literature, mythology and history. Peričić classified those patterns in 4 predominant types: basic intertextual pattern, mythologicalreligious-supernatural pattern, the pattern of citation and allusion, and metonymical or historical pattern.

The creative approach to writing articulated by the observed authors witnessed the very post-modern and fresh, "West European" poetics of the discussed period.

However, many of the relevant texts were neglected and their authors marginalized until the beginning of the 1990s, i. e. until the constituting of the new Croatian state. Therefore, the author emphasizes the need to revise the entire Croatian corpus of the observed period and to possibly redefine redefine the role/quality of some authors who remained in the shadow of a narrower or wider literary and theatrical reception.

Keywords: Croatian playwriting, second half of the 20th century, SFRJ (Ex-Yugoslavia), ideology, political repression and protest, intertextual patterns, foreign literature and culture

Započet ćemo ovaj prilog poznatom mišlju Emme Goldman koja u svom tekstu Moderna drama (Moćan širitelj radikalne misli) piše sljedeće: „[...] drama je sredstvo koje stvarno stvara povijest, širi radikalnu misao i među one do kojih inače ne bi doprla"1. Stoga držimo da se obojenost polemičkim (angažmanom) u dramskom tekstu gradi već na aludiranju na vrednote koje $\mathrm{u}$ društvenom sustavu postoje ili u njemu nedostaju (ili su pak narušene, po sudu autora književnoga teksta) - bilo na društvenoj bilo individualnoj razini. Međutim, u ovom izlaganju ipak posebno usmjeravamo pozornost prema onim dramskim tekstovima u kojima se politička polemičnost izražava upravo kroz sumnju i kritiku u odnosu na način djelovanja aktualne vladajuće ideološke snage te spram favoriziranju nekih svjetonazorskih polazišta odnosno zamisli kojima se nameće volja pojedinca, što je, dakako, osobitost u prvom redu totalitarnih društvenih uređenja. Imajući na umu ideološke okolnosti kakve su tijekom druge polovice protekloga stoljeća vladale u Hrvatskoj, tj. na hrvatskom teritoriju - najprije unutar SFR Jugoslavije kao države socijalističkoga ustroja odnosno vladajuće komunističke ideologije, a potom, po njezinu okončanju, u novoj hrvatskoj državi od početka devedesetih - možemo zaključiti kako su se one itekako zrcalile u dramskim

${ }^{1}$ Objavljeno u: E. Goldman: Anarhizam i drugi ogledi. Zagreb 2001. Ovdje preneseno s: http://www. stocitas. org/emma\%20goldman\%20drama.htm. 
tekstovima. Dapače, proučavanje hrvatske drame druge polovice XX. stoljeća navodi na ocjenu da je upravo dramski iskaz (uzimajući u obzir sve književne, tj. genološki odredive oblike), kako ga ovdje doživljavamo i predočavamo - a koji per se nije iznosio, deklarirao, afirmirao ili zastupao (bilo kakvo, tj. ikakvo) ideološko stajalište ili ideologijski sklop općenito - već je, naprotiv, na takve reagirao, na njih se osvrtao ili ih je pak stavljao pod kritičku lupu bio prostorom (upravo na tragu citiranih riječi Emme Goldman) angažmana, prosvjeda ili polemike koje je književnost u tim desetljećima mogla odnosno smjela artikulirati.

U slučaju da je opravdano vjerovati $u$ ono što je u popratnom tekstu za Matičino izdanje Ivšićeva Kralja Gordogana iz 1998. Zvonimir Mrkonjić nazvao: „snagom teatra da iskupi bespogovornu krvavu žestinu povijesti grotesknom igrom demaskiranja političkog fatuma“2, onda takav, dramski materijal (kao tekstualno polazište za moguću kazališnu izvedbu) - imajući na umu okolnosti u kojima je nastajao - podrazumijeva dovoljno poticajni i pregnantni objekt izučavanja koji je ovdje u fokusu zanimanja a koji je u kontekstu hrvatske književnosti iz doba o kojemu je riječ prerastao dapače u pravi subjekt književnoga, intelektualnog, proturepresivnog, etičkog i uopće humanističkog angažmana pojedinih hrvatskih dramatičara.

U nekoliko navrata autorica ovoga izlaganja na znanstvenim je skupovima govorila o hrvatskoj prošlostoljetnoj drami te pritom, među ostalim, isticala u domaćoj dramskoj književnosti karakterističnu dramatičnost nuđenja drame ${ }^{3}$. Naime, domaće dramsko stvaralaštvo - pa i ono političko-polemički obojeno - odrazilo se u velikoj mjeri kroz obrasce iskristalizirane u raznolikom susretanju dramskoga žanra sa svjetskom, tj. stranom književnošću i kulturom: pomoću intertekstualnoga posuđivanja ili prijenosa značenjskih i izražajnih sastavnica iz poznatih književnih (pred)tekstova, a uz to i putem mitskih/ mitoloških, religijskih, nadnaravnih, povijesnih, metapovijesnih itd. mehanizama. Pokazalo se da su takva sredstva bila na snazi u onim intelektualno iznimno pregnantnim - a time ujedno bogatim - dramskim tekstovima kojima se pisac odupirao represivnim političkim zamislima i autoritetima. $\mathrm{Na}$ temelju analize korpusa od pedesetak dramskih tekstova iz drugoga, posebice tzv. postmodernističkog, dijela protekloga stoljeća u Hrvatskoj dade se zaključiti kako se rečena intelektualna obremenjenost te politička pa i etička opterećenost stvarnošću u tim tekstovima iskazivala putem obrazaca koji su funkcionirali / funkcioniraju kao izražajno-značenjska sredstva svojevrsnoga maskiranja ili "kamuflaže" s ciljem dosezanja stanovitoga stupnja neizravnosti, prikrivenosti te $u$ konačnici i hermetičnosti poruke. Naime, ti su

2 Z. MrкоnנIć: Teatar Radovana Ivšića. U: R. Ivšić: Teatar. Zagreb 1998, s. 326-327.

${ }^{3}$ Usp. H. Peričić: Dramatičnost nuđenja dramskog. U: H. Peričić: Deset drskih studija (o književnim pitanjima, pojavnostima i sudbinama. Split 2011, s. 142-154. 
obrasci služili kao instrumenti zastiranja možda odveć riskantne, otvorene artikulacije prosvjeda spram npr. političkih autoriteta i vladajućeg aparata, te načina na koji oni djeluju. Uostalom, poznato je da su mnogi od dramatičara koji su se drznuli otvorenije izraziti vlastite teze doživjeli kao posljedicu sankcioniranje, intelektualno pa i egzistencijalno ugrožavanje i kažnjavanje ${ }^{4}$. Pisati tijekom pedesetih, šezdesetih, sedamdesetih pa i osamdesetih godina prošloga stoljeća o aktualnom političkom ustroju u bivšoj državi i poziciji Hrvatske u njoj te o ideološkim tendencijama ili protiv njih - nije bila bezazlena stvaralačka i umjetnička djelatnost jer je ona uglavnom oponirala političkim zadatostima, pri čemu su ponajviše stradavali intelektualci odnosno pojedinci skloni načinu pisanja kojim se, navodno, podrivala vlast ${ }^{5}$. Činjenica je da su neki od ovdje motrenih tekstova, koji su bili upriličeni na pozornici, vrlo brzo skidani s repertoara te su njihovi autori nerijetko marginalizirani i prešućivani. Spomenimo tako da je nakon prve izvedbe obustavljeno u Splitu prikazivanje Zatvorenoga poslijepodneva, "suvremene pasionske igre“ (kako stoji u podnaslovu) te je autor Vlatko Perković izgubio namještenje, a trnovit put do izvedbe imale su i drame poput Supekova Heretika i Šoljanove Dioklecijanove palače, dok je prikazivanje Kušanove Svrhe od slobode u režiji Miroslava Međimorca prestalo nakon samo dviju izvedaba na Dubrovačkim ljetnim igrama 1971. te jedne u Studentskom centru u Zagrebu iste godine ${ }^{6}$. Otuda se teško može zaobići pretpostavka kako u drugoj polovici XX. stoljeća, u književnostvaralačkom i kazališnom iskustvu u Hrvatskoj (u vrijeme dok je bila dijelom SFR Jugoslavije), obilježenima (protu)staljinističkim ideološkim utjecajem, agonijom političke nepodobnosti te važnim pokretima među ostalim, studentskim pobunama u šezdesetim i Hrvatskim proljećem u sedamdesetima - ima dramskih tekstova koji nikad nisu bili ni prihvaćeni za objavljivanje, i to upravo zbog svoje političke angažiranosti. Uspostava pak demokratske Republike Hrvatske početkom zaključnoga desetljeća XX. stoljeća donijela je nove dramske teme kojima su se njihovi autori osvrtali na nove dvojbe i poteškoće $u$ tek ustrojenom društvenom i političkom milieu; takve su društvene prilike bile popraćene pisanjem dramskih tekstova

${ }^{4}$ Vidi H. PerIČIĆ: Dodiri antike i suvremenosti na primjerima hrvatske drame druge polovice XX. stoljeća. U: Komparativna povijest hrvatske književnosti. Hrvatska književnost prema europskim (emisija i recepcija) 1940-1970. Zbornik radova VIII. sa znanstvenog skupa održanog 22.-23. rujna 2005. u Splitu. Ur. C. PAvlović, V. Glunčıć-BužAnčıć. Split 2006, s. 393-404.

${ }^{5}$ Usp. H. PeričIć: Ispisati istinu umjesto povijesti (Otpor ideološkom u izboru hrvatskih drama iz druge polovice XX. st.). „Poznańskie Studia Slawistyczne“ 2014, br. 6, s. 185-203.

${ }^{6}$ Usp. H. Peričić: Raznodobna istodobnost Kušanove Svrhe od slobode. U: Komparativna povijest hrvatske književnosti. Istodobnost raznodobnog. Tekst i povijesni ritmovi. Zbornik radova XII. Ur. C. Pavlović, V. Glunčić-Bužančić, A. Meyer-Fraatz. Split-Zagreb 2010, s. 346-361. 
kojima se reagiralo na novi politički i ideološki kontekst i način upravljanja državom (primjer za to je Brešanova drama Julije Cezar iz 1994.).

No, usredotočimo se na hrvatsku dramu do konca socijalističke, tzv. bivše Jugoslavije. Opasnosti za autore (prvenstveno se to odnosi na razdoblje od Drugoga svjetskog rata pa do konca SFRJ) nisu dolazile samo iz političkih vrhova, već i iz privatnih sukoba (temeljenim na interesima pojedinaca, o čemu se u povijestima domaće književnosti nije često pisalo) pa i profesionalnih konflikata i nesporazuma s moćnim kulturnjacima, što je često završavalo marginalizacijom i ostracizmom onih „koji su se drznuli“. Možda je dovoljno spomenuti slučaj dramatičara i redatelja Kalmana Mesarića, koji je tijekom druge polovice XX. stoljeća - a zapravo sve do svoje smrti 1983. bio zapostavljenim autorom te je bio prešućivan, među ostalim i zbog svojih polemičkih napisa u odnosu na M. Krležu i M. Begovića.

Angažiranost i/ili reagiranje na političku stvarnost u velikom broju dramskih tekstova druge polovice XX. st. odrazile su se u nas putem (barem) četiriju obrazaca kojima se u konačnici - čini se - demistificira književnost, ali i povijest: one više nisu shvaćene kao „papirnati“ proizvodi, umjetnički i znanstveni autoriteti, namijenjeni tek analizi i književnoteorijskom odnosno znanstvenopovijesnom razmatranju. Držimo da je uputno kazati nešto o tim obrascima pa i u svrhu razbijanja privida kako su (dramsko) književno stvaralaštvo (ili njegov autor odnosno autorica) - „,nedodirljivi“, neovisni o društvenom okruženju i povijesnim okolnostima. Zapravo, mogli bismo tvrditi da je slučaj upravo suprotan, pogotovu ako su pojedini pisac i njegovo djelo bili polemički djelatni, dakle duboko uključeni u vrijeme i prostor u kojemu su pisali.

Ovdje će autorica iznijeti samo opću podjelu na spomenute obrasce što joj se nametnula na razini intertekstualnog te na druge načine komparatistici relevantnog. $S$ vremenom se dakako otvara mogućnost proširenja rečene podjele i preciziranja njezinih sastavnica; spoznaje, postavke i pretpostavke iz prijašnjih proučavanja hrvatske dramske građe iz druge polovice XX. stoljeća narednim se izučavanjem - prirodno - dorađuju i preinačuju. Na tu je svoju klasifikaciju autorica ovih redaka ukazala u nekim svojim ranije objavljenim radovima ${ }^{7}$. Navodimo dakle temeljne obrasce, postupke, tipove

7 Slijede naslovi nekih od ranije objavljenih radova u kojima je autorica ovoga priloga obrađivala ovdje predmetnu temu:

Metaliterarnost $i$ multikulturalnost hrvatske drame druge polovice XX. stoljeća. U: Komparativna povijest hrvatske književnosti. Smjerovi i metodologije komparativnog proučavanja hrvatske književnosti. Zbornik radova X. Ur. C. PAvlović, V. Glunčıć-BužAnčić. Split 2008, s. 447-459.

Intertekstualnost u hrvatskoj drami druge polovice XX. stoljeća. Tipologija (u suautorstvu s Grgom Miškovićem). U: Krležini dani u Osijeku 2008. Tekst, podtekst i intertekst u hrvatskoj drami i kazalištu. Zbornik radova. Ur. B. Hećımović. Zagreb-Osijek 2009, s. 103-115.

Multiculturalism and the Return to Tradition. Elements of the Literatures in English in the Works of Some Postmodern Croatian Playwrights: Slamnig - Šoljan - Paljetak. U: Identities in 
(a time i odgovarajuće im primjere dramskih tekstova) dosezanja posudbenih, intertekstualnih ostvaraja na (meta)tekstualnoj i (multi)kulturalnoj razini:

a. intertekstualni (u užem smislu riječi) - predstavlja obrazac izabiranja i uporabe (primarnih) tekstova (genotekstova, hipotekstova, predtekstova) iz svjetske literature od staroga vijeka do XX. st. za nastanak novih, sekundarnih - hipertekstova, [meta]tekstova) ${ }^{8}$. U ovoj su kategoriji - imajući na umu i političnost izabranih tekstova - npr. spomenuta Brešanova drama iz devedesetih Julije Cezar (1994.; obj. 1997.) ${ }^{9}$, ali i njegova ranija i glasovitija iz šezdesetih - Predstava Hamleta u selu Mrduša Donja (1965.), potom Paljetkova Poslije Hamleta (1993. ${ }^{10}$ u odnosu na Shakespeareova djela, neke Slamnigove radiodrame te Marovićeva Antigona u Tebi (tebi) u odnosu na Sofoklovu tragediju (prva je verzija Marovićeva teksta iz 1980., dok je druga nastala 1983. a tiskana 1984.); tu se mogu pridodati i drame Pred vratima Hada Lade Kaštelan, koje su zapravo prerade Euripida. Kroz ovaj obrazac književni tekstovi na koje se novo djelo naslanja najčešće su uključeni u naslovu hiperteksta te je „posudba" izravna i lako uočljiva.

b. mitološko-religijsko-nadnaravni obrazac - predstavlja preuzimanje ili posudbu likova/bića ili fabularnih sklopova koji pripadaju Biblijï ${ }^{11}$, reli-

Transition in the English-Speaking World. Ur. By Nicoletta Vasta et. al. Udine 2011, s. 251-260.

Hrvatska religijska drama u mediteranskom kulturnom prostoru (Knjižeonost i politika u XX. st.) (u suautorstvu s Grgom Miškovićem). U: Zadarski filološki dani III. Zbornik radova s međunarodnoga znanstvenog skupa održana u Zadru i Ninu 5. i 6. lipnja 2009. Ur. Šimun MusA. Zadar 2011, s. 159-177.

Povijesno-metonimijski aspekt hrvatske drame druge polovice XX. st., „Forum“ 2012, br. 4-6, s. 590-603.

Neki obrasci artikuliranja političkog i polemičkog u hrvatskoj drami 20. st. (u suautorstvu s Marijanom Roščić). U: Krležini dani u Osijeku 2013. Ur. B. Hećımović. Zagreb-Osijek 2014, s. 176-186.

${ }^{8}$ Usp. V. Biтr: Pojmovnik suvremene književne teorije. Zagreb 1997, s. 154.

${ }^{9}$ Usp. H. Peričić: Metaliterarnost i multikulturalnost hrvatske drame druge polovice 20. stoljeća. / Summary: Metaliterariness and Multiculturalism in Croatian Drama from the Second Part of the 20th Century. U: Komparativna povijest hrvatske književnosti (,Smjerovi i metodologije komparationog proučavanja hrvatske književnosti“), zbornik radova X. / Tekstovi nastali povodom 50 godina Odsjeka za komparativnu književnost Filozofskog fakulteta Sveučilišta u Zagrebu (1956.-2006.). Ur. C. PAvlović, V. GLunčić-BužAnčić. Split 2008, s. 447-460.

${ }^{10}$ Opširnije o tomu vidi u: H. Peričić: Uvod u Paljetkovo dramsko stvaralaštvo za odrasle. U: Krležini dani u Osijeku 2000. („Hrvatska dramska književnost i kazalište - inventura milenija“, I. dio, zbornik. Ur. B. Hećımović. Zagreb-Osijek 2001, s. 267-276; te u: H. Peričıć: Multiculturalism and the Return to Tradition. Elements of the Literatures in English in the Works of Some Postmodern Croatian Playwrights: Slamnig - Šljan - Paljetak. U: Identities in Transition in the English-Speaking World. Ur. N. VAsta et. al. Udine 2011, s. 251-260.

${ }^{11}$ Usp. G. MišKović, H. Peričić: Hrvatska drama s religijskim elementima u razdoblju komunizma (Književnost $i$ društvo u drugoj polovici 20. stoljeća). U: Krležini dani u Osijeku 
gijskom uopće, grčkoj i rimskoj mitologiji, bajci, odnosno nadnaravnom ${ }^{12}$. U ovoj su skupini primjerice Krležin Aretej ili legenda od sv. Ancili, rajskoj ptici (1959.), Matkovićeva trilogija I bogovi pate (objedinjuje drame Heraklo, Prometej i Ahilova baština, 1962.), Paljetkova Orfeuridika (2000.), Glorija (1955.) Ranka Marinkovića, Marovićeva Antigona u Tebi (tebi) (1980.) i Solumov kraj (1996.) Pave Marinkovića. Uputno je naglasiti da posebnu problematiku čini hrvatska dramska literatura u kojoj je religijsko u službi isticanja opreke između dviju svjetonazorskih pozicija (religijske/kršćanske s jedne te komunističke s druge strane). Primjeri takvih tekstova Brešanove su drame Viđenje Isusa Krista u kasarni V. P. 2507, Nečastivi na filozofskom fakultetu (Moralitet u sedam slika); potom drama Ivana Bakmaza Šimun Cirenac te Mate Matišića Legenda o svetom Muhli. Inače, o sastavnicama vjerskog u hrvatskoj drami prošloga stoljeća vrlo je opsežnu i korisnu disertaciju napisao i na zagrebačkom Filozofskom fakultetu 2012. obranio Grgo Mišković13.

c. citatnost i aluzivnost - predstavlja posuđivanje/preuzimanje citata i tuđih fragmenata kojima se ukazuje ili aludira na primarni tekst kao stabilan $i$ utvrdiv $i z v o r^{14}$, pri čemu dolaze do izražaja ne samo (meta)literarne već i multikulturalne/(meta)kulturalne konotacije koje nudi novi dramski tekst. Navodim (i) ovdje primjer Krležina Areteja u odnosu na Danteove stihove, Perkovićevo Zatvoreno poslijepodne (1966.) (s aluzijama na novozavjetne tekstove), ali i Desničinu dramu Ljestve Jakovljeve (1961. ( $^{15}$ u kojoj aluzija na starozavjetnu priču razvidna iz samoga naslova služi potencijalnom razvijanju rasprave na temu prijevare ili samoprijevare (aluzija na prijevaru koju je naspram svom bratu učinio Jakov), tj. oportunizma u vladavini nacističkoga totalitarizma u kojemu se deklarativni humanizam i intelektualno licemjerje

2009. Hrvatska drama i kazalište i društvo. Ur. B. Hećımović. Zagreb-Osijek 2010, s. 162-177.

12 Svojevrsnu poetičku najavu takvoj skupini tekstova s nadnaravnim, bajkovitim, snovitim i nadrealnim elementima predstavljao je dramski tekst Radovana Ivšića Kralj Gordogan (1943.). (Usp. R. Ivšıć: U nepovrat, opet. Zagreb 2002, s. 297-303; također u: „Prolog“, god. 7, 1975.). I Ivšićevo stvaralaštvo kao i njegova sudbina kao autora primjer su spomenuta prešućivanja i marginaliziranja kao posljedice književnoga djelovanja i reagiranja na političku stvarnost. Dovoljno je navesti kako je drama Kralj Gordogan u Hrvatskoj objavljena tek 1975. godine u časopisu „Prolog“, a izvedena u režiji Vlade Habuneka četiri godine kasnije, 1979., u Teatru ITD. (Usp. Darko GašParović: O kazališnoj poetici Radovana Ivšića. U: Krležini dani u Osijeku 2001, Zagreb-Osijek 2002, s. 214).

${ }^{13}$ G. MıšKović: Religijski i biblijski elementi u hrvatskoj drami XX. stoljeća, rukopis. Obranjeno na Filozofskom fakultetu u Zagrebu 2012. Mentor: Helena Peričić; komentor: Boris SENKER.

${ }^{14}$ V. Biтr: Pojmovnik suvremene...

${ }^{15}$ Usp. H. Peričrć: Jezik ideologije i ideologija jezika u Desničinoj drami Ljestve Jakovljeve. U: Desničini susreti 2010. Zbornik radova. Ur. D. Roksandić, I. Cvijović Javorina. Zagreb 2011, s. 49-61. 
potiru s ciljem spašavanja vlastite kože i uzmiču pred kukavštinom, izdajom i tuđom pogibelji. Potom u ovoj skupini spominjem Kušanovu Svrhu od slobode (1971.) kao dramski tekst aluzivan u odnosu na Gundulićevu Dubravku (postupkom se ironizira gotovo sanktificirana povijest slobodnoga grada Dubrovnika i Dubrovačke Republike u kojima se u političke svrhe rasprodaje sve što je bilo stoljećima baštinjeno), zatim Gavranovu Kreontovu Antigonu (1983.) u odnosu na Sofoklov tekst, Šnajderova Hrvatskog Fausta (1981.) u odnosu na Goetheova Fausta.

d. metonimijski ili povijesni obrazac (u pojedinim primjerima moguće ga je nazvati i motivskim) - predstavlja izabiranje relevantnih motiva vezanih uz istaknute povijesne događaje, povijesne osobe i njihove živote ili djela, odnosno uz kulturu u kojoj je neko dramsko/književno djelo nastalo. Napominjem, međutim, da se ovaj tip uporabe, odnosno artikuliranja (povijesne) građe može ostvarivati i na razini metapovijesnosti, kada je dramski tekst tek djelomično ili prividno temeljen na povijesnočinjeničnom; takav postupak autorima često služi u svrhu stvaranja subverzivnog ili pak satiričnoga dramskog diskursa. Za to su primjeri Krležin Aretej (1959.), Supekov Heretik (1968.), Fabrijeve radiodrame Admiral Kristof Kolumbo (1968.) i Meštar (1970.) (o Michelangelu Buonarrotiju), Šoljanova Dioklecijanova palača (1969.), Kušanova Svrha od slobode (1971.), Šnajderov Hrvatski Faust i Marovićev Temistoklo (1983.). Ovdje naglašavamo da metapovijesno u nekima od ovdje spomenutih dramskih tekstova nipošto ne treba poistovjetiti s povijesnim, odnosno s povijesnočinjeničnim.

Dakako, valja imati na umu da - kad je riječ o navedenim obrascima često je na djelu kombiniranje nekoliko obrazaca među spomenutim četirima na koje se novi tekst oslanja na predtekst ili podtekst, odnosno na povijest koja može biti shvaćena ili kao niz objektivnih događaja ili kao interpretacija (u gore spomenutom meta- ili pseudopovijesnom smislu) tih istih događaja; dakle, drugim riječima - kao povijesna priča. Zbog toga se pojedine drame mogu uvrstiti u razne obrasce istodobno. Tako npr. Kušanova Svrha od slobode može pripadati i citatno-aluzivnoj, ali i metonimijskoj, tj. povijesnoj skupini. Brešanov Julije Cezar pripada povijesnom ili metonimijskom, ali isto tako i intertekstualnom i citatno-aluzivnom obrascu. Krležin Aretej pripada povijesnom, ali i mitološkom/religijskom/nadnaravnom te također citatnoaluzivnom tipu; dramske preradbe Euripida dramatičarke i dramaturginje Lade Kaštelan mogu biti u prvoj kategoriji, intertekstualnoj, ali i u obrascu mitološkom.

Posljednji u nizu gore navedenih posudbeno-intertekstualnih dramskih obrazaca - povijesni, odnosno metonimijski (d) - posebno se ističe u korpusu hrvatskih dramskih tekstova druge polovice XX. stoljeća kao polemički obilježen. Kako je rečeno: tekstovi iz te skupine primjeri su korištenja povijesnim motivima po metonimijskom načelu - uzimanja povijesnih osoba, kon- 
stelacije među njima, odnosno njihova života i djela kao situacijskog čvorišta. Temeljni obrazac tu zastupljen dade se generalizirati na tragu teza o obnavljanju povijesnih događaja, pri čemu se eksploatiraju povijesne činjenice i imena iz daljih, primjerice antičkih vremena (npr. Temistoklo, Julije Cezar, Dioklecijan te Aretej), ali također iz bliže povijesti (npr. Marko Antun de Dominis, splitski nadbiskup s prijelaza XVI. na XVII. stoljeće, žrtva inkvizicije, prikazan u Supekovu Heretiku, ili pak povijesni događaji poput Münchenskoga sporazuma iz rujna 1938., zastupljena u Krležinu Areteju; pa Drugi svjetski rat $\mathrm{u}$ metapovijesnom okviru Šnajderova Fausta). U tom smislu, stav prema povijesti i njezinim autorima, kroničarima, historicima koji nerijetko „izdaju istinu" - parafrazirat ćemo Tonča Petrasova Marovića - jer znaju djelovati kao falsifikatori i manipulatori koji se poigravaju odnosom između „duha, pravde i apsoluta" te proizvode "povijest koja se ponavlja“ (HP) - jedno je od načela vidljiva u korištenju povijesnim obrascem $u$ motrenom razdoblju hrvatske drame.

Povijesnost i povijesne sastavnice spomenutih drama nisu pak neovisne o multikultur(al)nim silnicama koje su vidljive u tim tekstovima. Tako je potonja, multikulturalnost, $\mathrm{u}$ rečenim dramama dotaknuta na primjer nastojanjem likova Apatrida iz Krležine drame Aretej da preuzmu novu ulogu vodiča kroz svijet legende kao sprege antike i kršćanstva, pri čemu se antika tumači kao temelj kršćanske kulture, ali i polazište za circulus vitiosus (u) povijesti čovječanstva a prema tumačenju Giambattiste Vica ${ }^{16}$. S tim u vezi Drago Šimundža primjećuje kako: „U tim je obzorjima Aretej, sa svojim gledištima i zaključcima, zaokruženi Krležin pogled na cjelokupnu stvarnost, ,nihilistički komentar svijeta" ${ }^{\prime \prime 17}$. Šimundža zaključuje: „,[...] dobro je da se pojavilo tako nemirno i problematično djelo s kritičkim pristupom totalitarističkim režimima i ljudskim nasiljima“118.

Navedeni dramatičari posežu za - među ostalim - povijesnim ili pseudopovijesnim informacijama te postupcima kako bi stvorili dramu koja živi, provocira i djeluje. U tom i takvom postupku razvidni su formalni i ontološki poticaji.

Razumljivo je da mnogi slučajevi preuzimanja iz svjetske književnosti, mita/mitologije (i religije) te povijesti nisu bili razumljivi širem čitateljstvu i/ili kazališnoj publici u vrijeme svoga nastanka: aluzivnost, citatnost, po-

${ }^{16}$ Giambattista Vico (Napulj, 23. VI. 1668. - Napulj, 23. I. 1744.), talijanski filozof i polihistor.

17 D. ŠımundžA: Bog u djelima hrvatskih pisaca (Vjera i nevjera u hrvatskoj književnosti 20. stoljeća), sv. 1. Zagreb 2004, s. 680. Šimundža u navodnicima rabi sintagmu Anatolija Kudrjavceva iz njegova članka Energija velikog negatora. O dramskom sustavu Miroslava Krleže. U: „Hrvatska obzorja“, Split, 1, 1993, s. 86.

18 ŠimundžA: Bog u djelima..., s. 683. 
vijesnost i intertekstualnost, na kojima se među ostalim grade ti tekstovi, mogle su biti razumljive tek školovanima, intelektualno mjerodavnima i nadasve - zainteresiranima. Uz to, oni koji dostatno ne poznaju povijesnopolitičke, ideološke pa i gospodarske prilike kakve su vladale na hrvatskom području u raznim fazama druge polovice XX. st. - bilo u SFRJ bilo u novoj državi u devedesetima - a tu posebice mislim na strano čitateljstvo i kazališnu publiku, teško će prepoznati odnosno "dešifrirati“ (intertekstualne) primjere zakriljenih, „kamufliranih“ značenja u dramskim tekstovima o kojima je ovdje bilo riječi te ih povezati s onodobno aktualnim povijesnim i političkim okolnostima i pojavama u bivšoj jugoslavenskoj državi: npr. s pitanjem zataškavanih komunističkih progona i zločina u SFRJ, s pitanjem postojanja mjesta za "politički preodgoj“ (poput notornoga Golog otoka), potom s već spomenutim pokretom Hrvatskoga proljeća, zbog kojega su mnogi njegovi sudionici i poklonici bili kažnjavani zatvorom ili ušutkavanjem, itd. Dodajmo tomu i pitanja religije te odnosa prema njoj $u$ bivšoj Jugoslaviji (u kojoj je, s obzirom na komunističku ideologiju, pojedinčevo iskazivanje vjerskog i vjeroispovijesti bilo zabranjeno), bez obzira o kojoj se vjeroispovijesti u (tadanjoj) Jugoslaviji odnosno Hrvatskoj radilo, a što je kao posljedicu imalo i protest artikuliran kroz dramske tekstove s elementima religijskog i nabožnog ${ }^{19}$.

Očigledno je dakle da se u velikoj mjeri predmetni instrumentarij u ovom prigodom motrenim dramama ostvarivao sa svrhom da bude funkcionalnim unutar domaćega kulturnog prostora i iskustva te poglavito intelektualnog dijela publike. No, način na koji se takav dramski diskurs artikulirao zapravo je značio eksploatiranje tzv. „vječnih tema“ o odnosu vlasti i pojedinca, države i intelektualca, (ne)istine i (ne)pravde, pri čemu je semantička "svevremenost" te teza o repetitivnosti povijesti a uz pomoć intertekstualnih mehanizama - zamijetit će i zamjerit će neki - „zastirala“ sadržaj pa i pogubnost onodobnih konkretnih životnih situacija, političkih pitanja i ideoloških prepreka. Razloge izostanka izravnosti i vidljivosti, tj. eksplicitnosti i/li eksponiranosti poruke i protesta u motrenoj hrvatskoj dramskoj književnosti valja, kako je rečeno, po svemu sudeći tražiti ne samo u postmodernističkoj poetici i utjecajima strane literature, već i u opisanim okolnostima represije te potencijalnoga i stvarnog kažnjavanja hrvatskih dramatičara, a što se u konačnici nerijetko odrazilo i kao neizvođenje ili pak zabrana izvođenja njihovih dramskih djela.

19 Vidi G. MišKović, H. Peričić: Hrvatska drama s religijskim elementima... U: Krležini dani u Osijeku 2009..., s. 162-17. 


\section{Literatura}

Biti V.: Pojmovnik suvremene književne teorije. Zagreb, Matica hrvatska, 1997.

BrešAn I.: Julije Cezar. U: I. BREŠAn: Spletke. Zagreb, Naklada Društva hrvatskih književnika, 1997.

BReŠAn I.: Predstava Hamleta u selu Mrduša Donja. Zagreb, ABC naklada, 2003.

Brustein R.: The Theatre of Revolt: An Approach to the Modern Drama. Chicago, Elephant Paperback, 1991.

Fabrio N.: Aluzione drame. Zagreb, Profil, 2007.

Fabrio N.: Predgovor "Tri drame“ Vlatka Perkovića. U: V. Perković: Tri drame (i skica za jedan operni libreto). Split, Logos, 1997, s. 9-13.

GašParović D.: O kazališnoj poetici Radovana Ivšića. U: Krležini dani u Osijeku 2001. Ur. B. Hećımović. Zagreb-Osijek, Zavod za povijest hrvatske knjiženosti, kazališta i glazbe HAZU-Odsjek za povijest hrvatskog kazališta-HNK Osijek-FF Osijek, 2002, s. $210-223$.

Gavran M.: Odabrane drame. Zagreb, Mozaik knjiga, 2001.

Goldman E.: Moderna drama (Moćan širitelj radikalne misli). U: E. Goldman: Anarhizam $i$ drugi ogledi. Zagreb, DAF, 2001. http://www.stocitas.org/emma\%20goldman\%20dra ma.htm [pristup: 17.07.2020].

Hartnoll P.: The Theatre, A Concise History, revised edition. London-New York, Thames and Hudson, 1991.

Hećimović B.: Dijalog i monolog u Matkovićevu djelu. U: Krležini dani u Osijeku 1987-19901991. Osijek-Zagreb, HAZU, 1992, s. 226-239.

Hrestomatija novije hrvatske drame. II dio 1945-1995. Ur. B. Senker. Zagreb, Disput, 2001.

Intertekstualnost \& autoreferencijalnost, zbornik. Ur. D. Oraić Tolić, V. ŽMegač. Zagreb, Zavod za znanost o književnosti Filozofskog fakulteta Sveučilišta u Zagrebu, 1993.

Ivšıć R.: Kralj Gordogan. U: R. Ivšıć: Teatar. Zagreb, Nakladni zavod Matice hrvatske, 1998.

Književno djelo Tonča Petrasova Marovića, zbornik radova. Ur. I. Frangeš. Split, Književni krug, 1997.

KrležA M.: Aretej ili Legenda o svetoj Ancili, rajskoj ptici. Sarajevo-Zagreb, Svjetlost-Školska knjiga, 1977.

KrLežA M.: Legende. Sarajevo-Zagreb, Oslobođenje-Mladost, 1981.

Kušan I.: Svrha od slobode. Drame. Zagreb, AGM, 1995.

Mannheim K.: Ideologija i utopija. Prev. K. Miladinov. Zagreb, Naklada Jesenski i TurkHrvatsko sociološko društvo, 2007.

Marinković R.: Glorija. U: Glorija i druge drame. Zagreb-Sarajevo, Globus-Svjetlost, 1988.

Marović T.P.: Antigona, kraljica u Tebi; Temistoklo. U: T.P. Marović: Odabrana djela II (Proza, drame). Split, Književni krug Split, 1992. (Prethodno objavljeno: T.P. Marović: Temistoklo, dramska historija. „Mogućnosti”, Split, Književni krug Split, 1984).

Marović T.P.: Osamnica. Zagreb, Cekade, 1984.

Matкоvić M.: I bogovi pate (drame). Zagreb, Zora, 1962.

MišKović G., Peričıć H.: Hrvatska drama s religijskim elementima u razdoblju komunizma. Književnost $i$ društvo u drugoj polovici 20. stoljeća. U: Krležini dani u Osijeku 2009. Hrvatska drama i kazalište i društvo. Ur. B. Hećımović. Zagreb-Osijek, Zavod za povijest 
hrvatske knjiženosti, kazališta i glazbe HAZU-Odsjek za povijest hrvatskog kazališta-HNK Osijek-FF Osijek, 2010, s. 162-177.

MišKović G., Peričić H.: Hrvatska religijska drama u mediteranskom kulturnom prostoru. (Književnost i politika u XX. st.). U: Zadarski filološki dani III. Zbornik radova s međunarodnog znanstvenog skupa održanog u Zadru i Ninu 5. i 6. lipnja 2009. Ur. Šimun Musa. Zadar, Sveučilište u Zadru (Odjel za kroatistiku i slavistiku), 2011, s. 159-177.

Mrduljaš I.: Dramski vodič: Od Vojnovića do Matišića (hrvatska dramatika 20. stoljeća). Zagreb, AGM-Hrvatsko društvo kazališnih kritičara i teatrologa, 1997.

Mrduljaš I.: Riječ koja se čuje (O dramatici Ivana Kušana). U: I. Kušan: Svrha od slobode. Zagreb, AGM, 1995.

Мrкоnנı́ Z.: Ogledalo mahnitosti. Zagreb, Biblioteka Prolog, 1985.

Nankov N.: Postmodernizam i kulturni izazovi. Prev. M. Paprašarovski. Zagreb, Hrvatsko filološko društvo, 2004.

NiKČEvić S.: Što je nama hrvatska drama danas. Zagreb, Naklada Ljevak, 2008.

Oraić Tolić D.: Teorija citatnosti. Zagreb, Grafički zavod Hrvatske, 1990.

Paljetak L.: Orfeuridika. „Forum“ 2000, br. 7-9, s. 915-932.

Paljetak L.: Poslije Hamleta. Zagreb, Hrvatska sveučilišna naklada, 1997.

Peričić H.: Uvod u Paljetkovo dramsko stvaralaštvo za odrasle. U: Krležini dani u Osijeku 2000. (Hrvatska dramska književnost i kazalište - inventura milenija), I. dio, zbornik. Ur. B. Hećımović. Zagreb-Osijek, Zavod za povijest hrvatske književnosti, kazališta i glazbe. HAZU-Odsjek za povijest hrvatskog kazališta-HNK Osijek-FF Osijek, 2001, s. 267-276.

PeričIć H.: Metaliterarnost i multikulturalnost hrvatske drame druge polovice XX. stoljeća / Metaliterariness and Multiculturalism in Croatian Drama from the Second Part of the $20^{\text {th }}$ Century. U: Komparativna povijest hrvatske književnosti Smjerovi i metodologije komparationog proučavanja hrvatske književnosti. / Tekstovi nastali povodom 50 godina Odsjeka za komparativnu književnost Filozofskog fakulteta Sveučilišta u Zagrebu (1956.-2006.). Ur. C. Pavlović, V. Glunčić-BužAnčić. Split, Književni krug Split, 2008, s. 447-460.

PeričIć H.: Tekst, izvedba, odjek (Trinaest studija iz hrvatske i inozemne dramske knjižeonosti). Zagreb, Erasmus, 2008.

PeričIć H.: Raznodobna istodobnost Kušanove Svrhe od slobode. U: Komparativna povijest hrvatske književnosti, Istodobnost raznodobnog. Tekst i povijesni ritmovi. Zbornik radova XII. Ur. C. Pavlović, V. Glunčić-Bužančić, A. Meyer-Fraatz. Split-Zagreb, Književni krug-Odsjek za komparativnu književnost FF Sveučilišta u Zagrebu, 2010, s. 346-361.

PeričIć H.: (Ne)poćudnost kao književnopovijesna konstanta i kriterij (primjeri iz domaće kritike 1914.-1940.) / (Un)suitability as a Literary-Historic Constant and Criterion (Examples from Croatian Criticism 1914-1940). U: Komparativna povijest hrvatske književnosti. Zbornik radova XIII. (Poetika i politika kulture nakon 1910. godine). Ur. C. PAvlović, V. Glunčić-Bužančić, A. Meyer-Fraatz. Split-Zagreb, Književni krug-Odsjek za komparativnu književnost Filozofskog fakulteta u Zagrebu, 2011, s. 17-30.

Peričıć H.: Jezik ideologije i ideologija jezika u Desničinoj drami Ljestve Jakovljeve. U: Desničini susreti 2010, zbornik radova. Ur. D. RoKsAndić, I. Cvijović Javorina. Zagreb, Centar za komparativnohistorijske i interkulturne studije Filozofskog fakulteta u ZagrebuPlejada, 2011, s. 49-61. 
Peričić H.: Multiculturalism and the Return to Tradition. Elements of the Literatures in English in the Works of Some Postmodern Croatian Playwrights: Slamnig - Šoljan - Paljetak. U: Identities in Transition in the English-Speaking World. Ur. N. Vasta et. al. Udine, Forum, 2011, s. 251-260.

PeričIć H.: Deset drskih studija (o književnim pitanjima, pojavnostima $i$ sudbinama). Split, Naklada Bošković, 2011.

Peričić H.: Letterature ,minori', identita culturale e globalizzazione. U: Europa neu denken. Region, Innovation und Kulturalität. Prev. Max Blažević. Hg. Michael Fischer, Programmbereich Arts \& Festival Culture, Schwerpunkt Wissenschaft und Kunst der Universität Salzburg-Universität Mozarteum, Media Design: Ritzner.at, Online-Publikation, Salzburg 2012, s. 43-52.

Peričić H.: Povijesno-metonimijski aspekt hrvatske drame druge polovice XX. st. „Forum“ 2012, br. $4-6$, s. 590-603.

Peričić H.: "Ispisati istinu umjesto povijesti"20 - (Otpor ideološkom u izboru hrvatskih drama iz druge polovice XX. st.), („Writing the Truth Instead of History”: Resistance to Ideology in some Croatian Plays in the Second Half of the 20th Century). „Poznańskie Studia Slawistyczne" 2014, br. 6, s. 165-182.

Perković V.: Zatvoreno poslijepodne: U: Idem: Tri drame (i skica za jedan operni libreto). Split, Logos, 1997. (Prvi tisak u: „Mogućnosti“ 1966, br. 2).

Reading the Past. Ur. Tamsin Spargo. New York, Palgrave, 2000.

Slamnig I.: Firentinski capriccio: jedanaest radio-drama. Rijeka, Izdavački centar Rijeka, 1987. Stamać A.: Zapravo, Šoljan. Zagreb, Društvo hrvatskih književnika, 2005.

Supek I.: Heretik. U: Inem: Drame. Zagreb, Matica hrvatska, 1971. (Prvi tisak u: „Rad JAZU“, 353, Zagreb 1968).

ŠımundžA D.: Bog u djelima hrvatskih pisaca: vjera i nevjera u hrvatskoj književnosti 20. stoljeća, sv. 1. Zagreb, Matica hrvatska, 2001.

ŠnAJDer S.: Hrvatski Faust. Zagreb, Centar za kulturnu djelatnost, 1982.

ŠNAJDER S.: Neki Jona. Starozavjetna legenda po novozavjetnom apokrifu. U: S. ŠNAJDER: Kamov: legende oko freske. Zagreb, Centar za kulturnu djelatnost SSO Zagreba, 1978. (Prvi tisak u: „Pitanja“ 1973, sv. 44/45).

Šoljan A.: Dioklecijanova palača. U: A. Šoljan: Devet drama. Zagreb, Matica hrvatska, 1970, s. 263-319.

ŠolJan A.: Romanca o tri ljubavi. U: Izabrana djela, I. Ur. P. BudAK. Zagreb, Nakladni zavod Matice hrvatske, 1987.

Vončina N.: Od ,Kneza' do ,Firentinskog capriccia'. „Republika“ 2005, br. 11, s. 62-74.

${ }^{20}$ U naslovu navedenoga rada autorica Helena Peričić poslužila se parafrazom stiha iz pjesničke zbirke Osamnica Tonča Petrasova Marovića (1984.) kojim pjesnik nagovješćuje falsificiranje povijesnih činjenica u povijesnim knjigama a koje obično „pišu pobjednici" (HP). 